\title{
SHADOW AS A STRUCTURAL COMPONENT OF PERSONALITY
}

\author{
Olga V. Korkunova \\ Ural State University of Railway Transport, Ekaterinburg, Russian Federation \\ Tatyana I. Bushueva \\ Ural State University of Railway Transport, Ekaterinburg, Russian Federation
}

\begin{abstract}
The article is devoted to topical issues in the field of the study of modern philosophical anthropology. The subject of the authors' consideration is the analysis of artistic works through the prism of the personality structure developed by C.G. Jung. The article, based on the work of Carl Gustav Jung, gives not only the study of Shadow as an individual component, but also as an important factor of personality's development. The authors have attempted to show how the Shadow externalizes and works and what a person's attitude towards it is. This research paper also reveals the ways of developing the Shadow component for achieving the positive personal enhancement. The analysis of fictional works showed that the writers documented the phenomenon of Shadow and started investigating and describing it long before philosophy scientists did it. The authors have analyzed the works in chronological order, consistently considering the texts of the beginning of XIX century, then the second half of XIX century, next the XX century, and finally the beginning of the XXI century. This approach allows us to show how gradually the deeper understanding of the phenomenon of Shadow went and draw the following conclusions: in the considered fiction texts the Shadow is antipode, antagonist and anti-hero of the main character. But a person and their Shadow are inseparable; one cannot simply suppress or remove the Shadow, the bad side of ego. In order to gain positive personal development a person must realize the negative dark side to meet with his her own Shadow. Thus, a person moves to perfection through awareness of individual imperfection.

Key words: personality, consciousness, unconscious, collective unconscious, Shadow.
\end{abstract}

УДК 111.12

ББК 87.52

\section{РОЛЬ ТЕНИ КАК СТРУКТУРНОГО КОМПОНЕНТА ЛИЧНОСТИ}

\section{Ольга Владимировна Коркунова}

Уральский государственный университет путей сообщения, г. Екатеринбург, Российская Федерация

\section{Татьяна Ивановна Бушуева}

Уральский государственный университет путей сообщения, г. Екатеринбург, Российская Федерация

Аннотация. Статья посвящена актуальной проблеме в области исследования современной философской антропологии. Предметом рассмотрения авторов является анализ художественных произведений через призму структуры личности, разработанной Карлом Густавом Юнгом. В статье, опираясь на работы К.Г. Юнга, дано исследование Тени как компонента личности и важного фактора ее совершенствования. Авторы сделали попытку показать, как проявляется и работает Тень, как человек относится к ней, что дает работа с ней и можно ли посредством работы с Тенью достичь позитивного развития личности. Проведенный анализ художественных произведений показал, что литераторы гораздо раньше ученых-философов зафиксировали феномен Тени и стали его описывать. Авторы статьи анализируют произведения в хронологическом порядке, последовательно рассматривая произведения начала XIX в., второй половины XIX в., XX в. и начала XXI века. Подобный подход позволяет показать, как постепенно шло углубленное осмысление феномена Тени, и сделать следующие выводы: Тень в рассмотренных художественных произведениях - это антипод, антагонист, антигерой главного персонажа. Но человек и Тень неразделимы, нельзя просто подавить или 
удалить теневую, дурную сторону личности. Для того чтобы подняться в собственном развитии, человек должен осознать свою отрицательную, темную сторону, встретиться с собственной Тенью. Таким образом, через осознание своего несовершенства человек идет к совершенствованию.

Ключевые слова: личность, сознание, бессознательное, коллективное бессознательное, Тень.

Тень - чернила, которыми пишет солнце, Тень - письмена моей лампы, Арсенал сожалений, Униженный бог.

Гийом Аполлинер. Тень

Говоря о человеке, мы акцентируем внимание на его личности и при этом имеем дело со множеством компонентов личности, каждый из которых заслуживает отдельного исследования. В своих работах швейцарский мыслитель Карл Густав Юнг выделил ряд новых компонентов, расположенных в коллективном бессознательном личности. Он показал, что коллективное бессознательное состоит из определенных структурных компонентов, а также то, что в нем может быть бесконечное количество архетипов. Юнг определяет архетипы как «эффект или осадок имевших место переживаний» [16, с. 242-243]. При возникновении определенной ситуации активизируется соответствующий этой ситуации архетип. Из всего множества компонентов коллективного бессознательного, репрезентирующих ситуации, Юнг выделяет Самость, Персону, Аниму, Анимус и Тень. Один из самых малоисследованных компонентов - Тень.

Тень можно отнести к группе компонентов, которые обращены внутрь индивида, то есть определяют развитие его внутреннего мира. Юнг определяет Тень как «опасный аспект непризнанной, темной половины личности» $[15$, с. 114]. «Тень является инстинктивной, проявленной в течение жизни, и входит в структуру деструктивной личности, которая является потенциальным источником зла» [19, р. 33]. В связи с этим Юнг пишет: «Тень - олицетворение всех “низменных человеческих проявлений”, низшая сторона личности, которая вырывается наружу. Разум уже не принадлежит человеку, он во власти Тени». Можно сказать, что Тень - это те мысли, чувства и совершенные на их основе поступки, которые мы не приемлем в себе. Юнг проводит параллель между Тенью и Чертом: «Черт - это вариант архетипа Тени, то есть опасного аспекта непризнанной тем- ной половины человека» [16, с. 244]. Его последователи характеризуют Тень по-разному. Английский исследователь Юнга Steve Page отмечает, что в этом описании есть некая двусмысленность, «заложенная в рамках концепции Тени с точки зрения термина "темнота". Это может быть связано с неизвестным: то, что находится за пределами “светлой части” сознания» [18, p. 2]. Немецкий исследователь, доктор философии, единомышленница и ближайшая коллега Юнга Marie-Louise von Franz в книге «Der Schatten und das Böse im Märchen» («Тень и Зло в сказках») пишет, что в народных преданиях «Тень и Зло связаны друг с другом» [17, S. 7]. В свою очередь российские исследователи акцентируют внимание на том, какую роль играет Тень в развитии человека. Так, Э.М. Спирова пишет: «Каждый человек имеет свою тень, подобно любой другой материальной субстанции, и именно наличие тени делает нас людьми» [10, с. 151].

Опираясь на методологию Юнга, проанализируем художественные произведения, в которых встречается персонаж Тень. Оттолкнемся от фундаментального исследования древних мифов народов мира американского ученого Джозефа Кэмпбелла, опубликованных в книге «Тысячеликий герой». Кэмпбелл считает, что в мифах персонаж Тень это «антагонист, воплощение зла, появляется в роли шута или юродивого» [6, с. 234]. Другими словами, в мифах разные воплощения персонажа Тень «представляют собой персонажей, совершающих ошибки, они - это тень субстанции; они символизируют неизбежное несовершенство царства теней» [6, c. 235]. Его исследования показали, что это создание мрака, поднимаясь из бездны, угрожает тому, кто дерзает обратиться к своему бессознательному. В связи с этим встает вопрос, как относиться к своей Тени, как работать с этой энергией и можно ли получить позитивный результат.

Адельберт фон Шамиссо в 1814 г. написал повесть «Удивительная история Петера 
Шлемиля» (Peter Schlemihls wundersame Geschichte). Это история Петера Шлемиля, неосознанно продавшего свою тень черту за кошелек Фортуната (табл. 1). Впоследствии Петер раскаялся в глупой, с его стороны, сделке, разрушившей покой и счастье его жизни. Эта утрата тени создала главному персонажу массу проблем: сделала его изгоем. Для общества он стал «другим», не таким как все, а именно «непорядочным». «Порядочные люди имеют обыкновение брать свою тень с собой, когда выходят на солнце» [8, с. 43]. Отсутствие тени воспринимается как недостаток или физический недуг. Шлемиль чувствует себя преступником, «отрезанным от всякой жизни», он описывает свою судьбу как жизнь «в несчастии с незавидной и мрачной участью». Хотя он освободился от тени, а именно от своей теневой или темной стороны, казалось бы, его жизнь должна стать менее проблемной, но вышло все наоборот: он вынужден скитаться по свету в поисках мира с самим собой. Он очень хочет вернуть свою тень. Черт предлагает вторую сделку: он вернет Шлемилю его тень, если тот отдаст ему свою душу. Главный персонаж отказывается заключить эту сделку. Он выбрасывает волшебный кошелек черта в пропасть. После этого он осознает: «И вот я сидел без тени и без денег, но тяжкий груз свалился с моей груди, я был весел. Если бы я также не потерял любовь, или если бы только чувствовал себя невиновным при этой потере, полагаю, я мог бы быть счастливым» [8, с. 234]. Осознав, что уже не сможет вернуть свою тень, Шлемиль находит свое счастье в науке, странствуя по всему миру в поисках новых научных открытий. Он осознает, что только напряженная работа может защитить его от гнетущих, разрушающих мыслей [8, с. 244]. Шамиссо в заключении обращается к читателям: «Ты же, дорогой друг, если хочешь жить среди людей, научись чтить прежде тень, а лишь затем деньги» [8, с. 286].

Эрнст Теодор Амадей Гофман в 1815 г. написал сказочную повесть «Приключения в новогоднюю ночь» (см. табл. 2). Молодой немец Эразм Спикер отдает свое отражение (иллюзорно мерцающую Тень) прекрасной Джульетте, помощнице Дьявола. После этого он становится несчастным. Окружающие его люди, обнаружив, что он не отражается в зеркале, называют его «негодяем и злодеем». Он становится изгоем общества. Жена Эразма ему говорит, что «без отражения сделаешься посмешищем для людей, и не сможешь быть порядочным и безупречным отцом семейства, внушающим уважение жене и детям» $[4$, c. 93]. В итоге он отправляется странствовать по свету и встречается с Петером Шлемилем, также страдающим от отсутствия Тени, героем сказки Шамиссо. «Они чуть было не договорились составить компанию и путешествовать вместе: Эразм Спикер отбрасывал бы надлежащую тень, а Петер Шлемиль отражался бы подобающим образом в зеркалах, однако из этой затеи ничего не вышло» [4, c. 93-94]. Это заключение автора наводит на

\section{Персонаж «Тень» в повести «Удивительная история Петера Шлемиля»}

Таблица 1

\section{А. фон Шамиссо}

\begin{tabular}{|c|c|}
\hline Главный герой произведения & Молодой человек Петер Шлемиль, продавший свою тень за богатство \\
\hline Наличие героя-антипода & Нет \\
\hline $\begin{array}{l}\text { Характеристика/Описание } \\
\text { персонажа «Тень» }\end{array}$ & $\begin{array}{l}\text { На протяжении всей повести А. фон Шамиссо использует эпитеты, опи- } \\
\text { сывающие «Тень»: прекрасная [8, с. 32], великолепная [8, с. 32], бесцен- } \\
\text { ная [8, с. 34], благородная [8, с. 35], сущая, реальная тень [8, с. 151], со- } \\
\text { кровище [8, с. 57]; после потери хозяина - бедная, униженная [8, с. 157], } \\
\text { вынужденная прислуживать [8, с. 157] }\end{array}$ \\
\hline Особенность «Тени» & $\begin{array}{l}\text { Тень является большой ценностью для темных сил (черт, дьявол). Когда } \\
\text { главный герой продает свою тень за деньги, отсутствие тени приводит } \\
\text { его к утрате мира с самим собой }\end{array}$ \\
\hline $\begin{array}{l}\text { Как «Тень» интерпретирует- } \\
\text { ся с позиции теории Юнга }\end{array}$ & $\begin{array}{l}\text { В работах Юнга есть описание архетипа Черт или Дьявол - это вариант } \\
\text { архетипа Тени и компонент коллективного бессознательного. Выше бы- } \\
\text { ло сказано, что Юнг проводит параллель между Тенью и Чертом. Не } \\
\text { случайно в повести Шамиссо черт заинтересован в приобретении тени } \\
\text { главного персонажа }\end{array}$ \\
\hline
\end{tabular}


мысль, что не вышло либо из-за несовместимости персонажей, либо потому, что сообщество нового типа людей, лишенных тени, является бесперспективным.

У Ханса Кристиана Андерсена мы находим сказку «Тень» (1864), которая также посвящена философскому осмыслению Тени человека (табл. 3). В ней описывается жизнь ученого, который пишет книги об истине, добре и красоте, но его труды остаются невостребованными. Тень ученого с помощью ловкости и денег добивается высокого социального статуса. Ученый в отчаянии, его книги не нужны людям. Тень предлагает ему путешествовать вместе. Ученому предлагается роль спутника тени. Вследствие этого «тень стала господином, а господин тенью» [1, с. 79]. Изза доброго нрава ученый многое прощает своей тени. Например, он говорит своей тени «вы», а тень называет его на «ты». Во время путешествия тень встречает принцессу. Принцессе очень понравилась тень ученого, и она решила задать ему трудные вопросы о солн- це, луне и о внешних и внутренних свойствах человеческой природы [1, с. 81]. Тень не смогла ответить и ушла от ответа, сказав, что вопросы очень простые и даже его тень (ученый) сможет ответить на них. Ученый ответил на все вопросы. Принцесса решила, что если тень так хорошо ответила на вопросы, то как должен быть умен человек, обладающий этой тенью. После она решила выйти замуж за тень. Тень предлагает ученому забыть, что он человек, и остаться навсегда тенью. Ученый не готов мириться с обманом, который предлагает ему тень. В итоге ученого казнят, а тень женится на принцессе.

Фридрих Вильгельм Ницше в 1880 г. пишет произведение «Странник и его тень» (Der Wanderer und sein Schatten). Свои идеи философ выражает в блестящих афоризмах. Другими словами, это «книга относительных и абсолютных знаний Ницше» (см. табл. 4). Мыслить для Ницше всегда являлось страстью. В этот сборник он поместил свои истины. Один из афоризмов называется «Светлая

Таблиияа 2

\section{Персонаж «Тень» в повести «Приключения в новогоднюю ночь» Э.Т.А. Гофмана}

\begin{tabular}{|l|l|}
\hline Главный герой произведения & $\begin{array}{l}\text { Молодой немец Эразм Спикер, имеющий жену и сына. «Почтенный отец } \\
\text { семейства». Отдал свою тень ради безумной страсти/любви к женщине }\end{array}$ \\
\hline Наличие героя-антипода & Нет \\
\hline $\begin{array}{l}\text { Характеристика/Описание } \\
\text { персонажа «Тень» }\end{array}$ & $\begin{array}{l}\text { «Это отражение в зеркале. Призрачная иллюзия “я”, мерцающая в зерка- } \\
\text { ле. Изменчивый, зыбкий образ» [4, с. 85]. «Иллюзорное мерцающее “я”» } \\
{[4, \text { с. } 87] . \text { «Красивое, в точности верное отражение» [4, с. 94] }}\end{array}$ \\
\hline Особенность «Тени» & В повести Гофмана Тень абстрактна \\
\hline $\begin{array}{l}\text { Как «Тень» интерпретирует- } \\
\text { ся с позиции теории Юнга }\end{array}$ & $\begin{array}{l}\text { Тень - необходимая составляющая человека. Существует глубокая связь } \\
\text { между человеком и его тенью. Отражение/Тень - необходимый компо- } \\
\text { нент личности. Ее утрата делает личность неполноценной для общества }\end{array}$ \\
\hline
\end{tabular}

\section{Персонаж «Тень» в сказке «Тень» Х.К. Андерсена}

Таблийа 3

\begin{tabular}{|l|l|}
\hline Главный герой произведения & $\begin{array}{l}\text { Ученый. Человек умный и молодой [1, с. 73]. Пишет книги об истине, } \\
\text { добре и красоте [1, с. 75] }\end{array}$ \\
\hline Наличие героя-антипода & Тень \\
\hline Характеристика/Описание & $\begin{array}{l}\text { На протяжении сказки персонаж «Тень» трансформируется. В первую } \\
\text { встречу после длительного отсутствия - невероятно худощавый человек, } \\
\text { одетый очень элегантно, как знатный господин [1, с. 75]. Во вторую } \\
\text { встречу и последующие - толстеющий человек }\end{array}$ \\
\hline Особенность «Тени» & $\begin{array}{l}\text { Тень уже является персонифицированной и социализированной. Играет } \\
\text { сугубо отрицательную роль. Обращает внимание на человеческие пороки } \\
\text { и людские грехи, тем самым нагоняет страх на людей [1, с. 78] }\end{array}$ \\
\hline $\begin{array}{l}\text { Как «Тень» интерпретирует- } \\
\text { ся с позиции теории Юнга }\end{array}$ & $\begin{array}{l}\text { В этой сказке Тень победила. Ученый с его сознанием вступил в борьбус } \\
\text { бессознательным, и бессознательное оказалось сильнее сознания. Сам } \\
\text { итог говорит о том, что сознательные установки героя терпят фиаско, а } \\
\text { Тень набирает силу (толстеет) и достигает успеха }\end{array}$ \\
\hline
\end{tabular}


тень»: «Близко, совсем близко к мрачным людям всегда почти находится как бы связанная с ними светлая душа. Это словно отрицательная тень, отбрасываемая ими» [9, с. 246]. Сами условия жизни, жестокая реальность, борьба за свое существование мобилизуют Тень человека, и на второй, «теневой» план уходят те неработающие качества, которые не востребованы в данный момент (например, доброта). Здесь мы видим вертикальное (сознание - бессознательное) и горизонтальное (условия жизни в обществе) движение.

В повести Роберта Льюиса Стивенсона «Странная история доктора Джекила и мистера Хайда» (1886) два персонажа: доктор Генри Джекил - ученый, ведущий деятельную жизнь, занимающийся благотворительностью, и Эдвард Хайд, «совершенно аморальный тип». На самом деле это две стороны одного человека. В повести описывается борьба сторон, фиксируется раздвоение личности, когда определенную часть времени человек реализует свои лучшие стороны, а определенную часть реализует Тень (см. табл. 5). В результате происходит не только раздвоение личности, но и двойная жизнь, выдержать которую человек не может. Главный герой погибает в физических муках и муках совести. Хочется обратить внимание на то, что муки усилены вдвойне. В этом произведении впервые показано взаимодействие человека со своей Тенью не в виде отказа от Тени, а в виде раз- двоения личности и ведения двойной жизни. Автор пытается дать объяснение этому феномену, поэтому в предсмертном письме Генри Джекил объясняет все произошедшее с ним. Джекил считал, что худшим его недостатком было нетерпеливое стремление к удовольствиям, но в связи с этим возникло раздвоение личности, так как эта наклонность мешала ему казаться серьезным и почтенным. Джекил боялся потерять свое положение в обществе: «Поэтому я начал скрывать свои развлечения, и к тому времени, когда я достиг зрелости и мог здраво оценить пройденный мною путь, мое положение в обществе, двойная жизнь давно стала для меня привычной. Немало людей гордо выставляли бы напоказ те уклонения со стези добродетели, в которых я был повинен, но я, поставив перед собой высокие идеалы, испытывал мучительный, почти болезненный стыд и всячески скрывал свои вовсе не столь уж предосудительные удовольствия. Таким образом, я стал тем, чем стал, не из-за своих довольно безобидных недостатков, а из-за бескомпромиссности моих лучших стремлений - те области добра и зла, которые сливаются в противоречиво двойственную природу человека, в моей душе были разделены гораздо более резко и глубоко, чем они разделяются в душах подавляющего большинства людей» [11, c. 443]. Стивенсон обращает внимание на то, что Джекил не лицемер: он «был самим со-

Таблица 4

Персонаж «Тень» в произведении «Странник и его тень» Ф.В. Ницше

\begin{tabular}{|l|l|}
\hline Главный герой произведения & Странник \\
\hline Наличие героя-антипода & Тень \\
\hline парактеристика/Описание & Тень - отрицательная составляющая. \\
& Странник: «Человеческая тень - это его тщеславие...» [9, с. 137]. \\
& «Тень, как и свет, необходима для того, чтобы придать прелесть лицу, \\
& выразительность речи, доброту и твердость характеру. Они не противни- \\
ки, а, скорее, союзники, дружно идущие рука об руку; и, когда исчезает \\
свет, то пропадает и тень» [9, с. 138]
\end{tabular}


бой и когда, отбросив сдержанность, предавался распутству, и когда при свете дня усердно трудился на ниве знания или старался облегчить чужие страдания и несчастия» [11, c. 443]. Это вечная война двух начал, которую человек часто ощущает в себе, «человек на самом деле не един, но двоичен» [11, с. 444]. Мы видим, как детально и подробно Стивенсон описывает и оценивает внутреннюю борьбу человека, принявшего и осознавшего свою Тень.

В сказке Оскара Уайльда «Рыбак и его душа» (1891) есть два персонажа - Рыбак и его Тень-душа (табл. 6). Уайльд пишет: «То, что люди называют своей тенью, не тень их тела, а тело их души» [12, с. 329]. Рыбак ради любви к Деве морской один раз смог отделить от себя свою Тень, и «она поднялась и предстала перед ним, точно такая, как он» $[12$, c. 330]. Рыбак прогнал от себя Тень, но связь между ними не исчезла. Тень сначала жалобно молила, неустанно просила его воссоединиться. Затем стала искушать его: в первый год - мудростью, во второй - богатством, на третий - танцующей женщиной. Два года Рыбак устоял, на третий - не смог. Воссоединился со своей тенью, чтобы она помогла ему найти прекрасную танцующую женщину. В этом путешествии тень обманом заставляет Рыбака совершить аморальные поступки: украсть, ударить ребенка и убить человека. Все это Тень объясняет тем, что когда Рыбак ее прогнал, не дав ей сердца, она научилась этим деяниям и полюбила их [12, с. 345]. Рыбак пытается избавиться от Тени, но осознает, что «злая Душа останется с ним навсегда» $[12$, с. 346$]$. В противоборстве со своей Тенью Рыбак погибает.

Таблица 5

Персонаж «Тень» в повести «Странная история доктора Джекила и мистера Хайда»

\section{Р.Л. Стивенсона}

\begin{tabular}{|l|l|}
\hline Главный герой произведения & Доктор Джекил \\
\hline Наличие антипода & Мистер Хайд \\
\hline $\begin{array}{l}\text { Характеристика/Описание } \\
\text { персонажа «Тень» }\end{array}$ & Отрицательный герой \\
\hline Особенность «Тени» & $\begin{array}{l}\text { В силу этих идей полно описана борьба двух начал в человеке (положи- } \\
\text { тельных и отрицательных компонентов личности). Тень исходит из ли- } \\
\text { кования чувств }\end{array}$ \\
\hline $\begin{array}{l}\text { Как «Тень» интерпретирует- } \\
\text { ся с позиции теории Юнга }\end{array}$ & $\begin{array}{l}\text { В жизни главного героя Тень стала такой же доминантой, как сознание, } \\
\text { сформированное установками общества. Автор показывает, как развивает- } \\
\text { ся взаимодействие личности и Тени. Описано явное раздвоение личности. } \\
\text { Стивенсон показал, что раздвоение личности заканчивается трагически }\end{array}$ \\
\hline
\end{tabular}

Таблица 6

Персонаж «Тень» в сказке «Рыбак и его душа» О. Уайльда

\begin{tabular}{|l|l|}
\hline Главный герой произведения & $\begin{array}{l}\text { Молодой Рыбак, который ради любви к Деве морской избавляется (про- } \\
\text { гоняет) свою душу-тень }\end{array}$ \\
\hline Наличие героя-антипода & Тень - Душа \\
\hline $\begin{array}{l}\text { Характеристика/Описание } \\
\text { персонажа «Тень» }\end{array}$ & «Люди называют своей тенью не тень их тела, а тело их души» [12, с. 329] \\
\hline Особенность «Тени» & $\begin{array}{l}\text { Тень }=\text { Душа. Уходя от Рыбака, она просит его сердце. Рыбак сердце не } \\
\text { отдает. Тень становится злой }\end{array}$ \\
\hline $\begin{array}{l}\text { Как «Тень» интерпретирует- } \\
\text { ся с позиции теории Юнга }\end{array}$ & $\begin{array}{l}\text { Уайльд феномен Тени осмысляет в плане душевных переживаний и ду- } \\
\text { ховного развития личности. Хотя Рыбак прогнал от себя Тень-душу, но } \\
\text { связь не исчезла. Это говорит о том, что жизнь души богата и просто про- } \\
\text { гнать или выгнать из нее какие-то фрагменты нельзя. По сюжету сказки } \\
\text { мы видим, что, отделив себя от своей Тени, Рыбак не улучшил свою } \\
\text { жизнь. В финале, пройдя через испытания, Рыбак осознает свои ошибки. } \\
\text { Но его жизнь заканчивается трагически, он погибает }\end{array}$ \\
\hline
\end{tabular}


Хорошо раскрывает смысл проблемы Тени для жизни личности и Евгений Шварц в пьесе «Тень» (1938-1940), написанной по сказке Андерсена. Главные персонажи пьесы те же - молодой Ученый и его Тень (табл. 7). Главная цель Ученого - сделать людей счастливыми, главная цель Тени - добиться власти любым путем. Тень - полная противоположность Ученому, но она может оказаться сильнее, чем следует, и «она ближе к земле» (другими словами, ее желания более приземленные). Шварц пишет, что «люди не знают теневой стороны вещей, а именно в тени, в полумраке, в глубине и таится то, что придает остроту нашим чувствам» [14, с. 219]. Шварц избегает раздвоения личности. Он рассматривает личность как единую целостность. Когда казнят Ученого, погибает и Тень. Когда Ученого воскрешают, воскрешается и Тень. Эти два героя не могут друг без друга. На самом деле Тень выражает бессознательное амбициозное стремление Ученого. Конец этого произведения более показателен. Тень исчезает, а Ученый уезжает из страны, движимый желанием изменить свою жизнь.

В романе Урсулы Ле Гуин «Волшебник Земноморья» (1968) главный персонаж - молодой волшебник Гед, рвущийся к могуществу, славе, обретению над людьми неограниченной власти, сулящей силу и богатство (см. табл. 8). Из-за проявлений собственной гордости Гед совершает большую ошибку произносит запрещенное заклинание, в силу которого в мир проникает великое зло. Вместе со злом в мир приходит чудовище - некая
Тень, которая хочет убить душу Геда и занять его тело. Чтобы победить Тень, Геду необходимо преодолеть много препятствий. «Путь этот привел его к погоне за страшной Тенью, и он попал в такие края, что лежат за невидимыми морями и простираются до самых границ темного царства смерти» [7, с. 10-11]. Гед победил злого колдуна во дворце Терренон на острове Осскил, не попал в ловушку Древних Сил, отбился от слуг Камня, на острове Пендоре победил дракона. Только изменив себя, поняв свое предназначение, Гед смог победить Тень. «В этом сражении Гед не проиграл, и не выиграл, но, назвав Тень Смерти собственным именем, как бы соединил две половинки своей души - стал человеком, который, познав собственное “я”, не может оказаться во власти иной силы и сам повелевает своей душой, а потому тратит жизнь только ради жизни и никогда - ради разрушения, боли, ненависти или воцарения тьмы» [7, с. 176].

В романе Нила Геймана «Американские боги» (2001) описывается загадочный и молчаливый главный персонаж Тень (см. табл. 9). В романе переплетаются элементы американской культуры, фэнтези и элементы древней и современной мифологии.

Проведенный анализ художественных произведений показал, что литераторы гораздо раньше ученых зафиксировали феномен Тени и стали его описывать. В начале (произведения начала XIX в.) акцент делался на том, что Тень - неотъемлемая часть личности, теряя которую человек лишается покоя и счастья, признания общества. Он посвящает свою

Таблииа 7

\section{Персонаж «Тень» в пьесе «Тень» Е. Шварца}

\begin{tabular}{|c|c|}
\hline Главный герой произведения & Ученый \\
\hline Наличие героя-антипода & Тень \\
\hline $\begin{array}{l}\text { Характеристика/Описание } \\
\text { персонажа «Тень» }\end{array}$ & $\begin{array}{l}\text { Тень - полная противоположность ученому }[14, \text { с. } 198] \text {. Тень ближе к } \\
\text { земле (приземленной стороне жизни). «Тень знает теневую сторону ве- } \\
\text { щей» [14, с. } 233] \text {. «Люди не знают теневой стороны вещей, а именно в } \\
\text { тени, в полумраке, в глубине и таится то, что придает остроту нашим } \\
\text { чувствам. В глубине вашей души - я (тень)» }[14, \text { с. } 219]\end{array}$ \\
\hline Особенность «Тени» & $\begin{array}{l}\text { «... тень может победить только на время. Весь мир-то держится на нас, } \\
\text { на людях, которые работают» }[14, \text { с. } 227] \text {. Шварц избегает описания раз- } \\
\text { двоения личности. Он рассматривает личность как единую целостность. } \\
\text { Когда казнят Ученого, погибает и Тень }\end{array}$ \\
\hline $\begin{array}{l}\text { Как «Тень» интерпретирует- } \\
\text { ся с позиции теории Юнга }\end{array}$ & $\begin{array}{l}\text { Шварц впервые фиксирует целевые установки, к которым стремятся соз- } \\
\text { нание человека и Тень. У Шварца впервые показано, что человек может } \\
\text { взять под контроль свою Тень, в результате чего личность нацеливается } \\
\text { на поиски нового в своей жизни }\end{array}$ \\
\hline
\end{tabular}


Персонаж «Тень» в романе «Волшебник Земноморья» У. Ле Гуин

\begin{tabular}{|l|l|}
\hline Главный герой произведения & Молодой волшебник Гед \\
\hline Наличие героя-антипода & Тень \\
\hline Характеристика/Описание & Тень Смерти. Вызывает у человека ужас. Черная тень. «Нечто темное, \\
бесформенное, похожее на обрывок чей-то черной тени, своей чернотой \\
выделяюееся даже в окружающей ее тьме» [7, с. 27]. Сгусток тьмы, \\
ужасное существо
\end{tabular}

Таблица 9

Персонаж «Тень» в романе «Американские боги» Н. Геймана

\begin{tabular}{|l|l|}
\hline Главный герой произведения & Молодой человек по имени Тень \\
\hline Наличие героя-антипода & $\begin{array}{l}\text { Отец Тени - Среда (древний бог, Вотан, Один). Уверенный в себе чело- } \\
\text { век, жизненная сила. Драйв. Девиз: Ты - это возможность }\end{array}$ \\
\hline $\begin{array}{l}\text { Характеристика/Описание } \\
\text { персонажа «Тень» }\end{array}$ & $\begin{array}{l}\text { Здоровенный и тупой. Добрый, сопереживающй. По мнению окружаю- } \\
\text { щих, он не живет, а существует. Такой вид, будто толком не знает, что он } \\
\text { тут делает. Человек-тень. Отправляется в тюрьму ради своей жены. } \\
\text { «В детстве я никогда не мог найти общий язык с другими детьми, поэто- } \\
\text { му молча ходил хвостом за взрослыми» [2, с. 319] }\end{array}$ \\
\hline Особенность «Тени» & Персонаж Тень -положительный герой, который борется со злом \\
\hline $\begin{array}{l}\text { Как «Тень» интерпретирует- } \\
\text { ся с позиции теории Юнга }\end{array}$ & $\begin{array}{l}\text { В романе показан процесс развития личности. Посредством ухода от те- } \\
\text { невой стороны герой преодолевает себя, чтобы стать полноценным чле- } \\
\text { ном общества }\end{array}$ \\
\hline
\end{tabular}

жизнь путешествиям и занятиям наукой. Это говорит о том, что человек находится в состоянии поиска того, как обрести мир с собой. Но достичь этого он не может и погибает.

В произведениях второй половины XIX в. отделение Тени от человека описывается как ее самостоятельное существование в обществе. Акцент сделан на взаимодействии и диалоге Тени и Героя как двух существ, существующих отдельно друг от друга. Интересно, что Тень доминирует, добивается жизненного успеха, а Герой борется с ней, но погибает. Таким образом, выявляются возможности Тени при ее доминировании в человеке и трудности победы над ней.
В произведении Стивенсона сделана попытка по-другому осмыслить феномен Тени. Человек реализует обе стороны своей личности, но это приводит к раздвоению личности и двойной жизни Героя, которой он не выдерживает и гибнет. Феномен Тени четко предстает феноменом психики человека.

В произведении О. Уайльда (1891 г.) Тень предстает как феномен души, то есть внутреннего, психического мира человека. В нем представлена другая линия взаимодействия Героя с Тенью. Сначала Герой изгоняет Тень, исключая ее из своей жизни. Но Тень преследует Героя и просится назад. Когда Герой уступает Тени и воссоединяется с ней, 
его душа становится злой и толкает его на преступления. В противоборстве со злой душой человек гибнет. Таким образом, самостоятельное решение человека исключить Тень не избавляет его от нее, а воссоединение с ней трансформирует его душу - в ней побеждает зло. Борьба со злом, душевная борьба заканчиваются гибелью человека.

$\mathrm{XX}$ в. углубляет осознание феномена Тени. Четко выявляется, что Тень дает человеку другую мотивацию и устремленность в жизни - ориентацию на власть, могущество, богатство. Когда Тень добивается успеха в достижении этих целей, Герой не избавляется от нее, а побеждает словами: «Тень, знай свое место». Иначе говоря, человек признает свою Тень, осознает опасность ее проявлений и устанавливает контроль сознания над ней.

К этому времени - середине XX в. - Тень уже становится предметом изучения науки, и мы напрямую видим влияние психических исследований на художественные произведения. В этих произведениях акцент перенесен на борьбу с Тенью и победу над ней, что позволяет Герою познать собственное «Я», управлять душой и обрести позитивную цель жизни.

В научных исследованиях К. Юнга Тень выделена как компонент бессознательного. Она рассматривается в соответствии с разработанным им механизмом взаимодействия сознания и бессознательного.

Юнг указывал на вопиющую несознательность, которую демонстрирует большая часть людей. Большинство людей знают, что они эгоцентричны и эгоистичны, но прячут, скрывают свои отрицательные черты. Конечно, есть исключения - люди, которые гордо демонстрируют обществу свои отрицательные качества (например, агрессивность и жадность), в то время как в теневой части у этих людей будут чувствительность и сентиментальность. Другую группу исключений составляют преступники и социопаты.

Юнг отмечал, что человеку самому трудно осознать свою Тень, но окружающие люди, как это ни странно, эту Тень видят. Есть русская поговорка, хорошо описывающая эту ситуацию: «В чужом глазу соринку видим, в своем - бревна не замечаем». Другими словами - видеть мелкие недостатки у других, не замечая больших изъянов у себя.
Человек в силу того, что Тень - это те мысли и чувства, которые он не приемлет в себе, старается ее подавить, скрыть. Это неверно. Необходимо принять Тень в самом себе. По мнению Юнга, у Тени есть не только отрицательные, но и положительные свойства. Он пишет: «Доныне считалось, что человеческая тень - это источник всего существующего зла; теперь же, на основании тщательно проведенных исследований, можно с уверенностью утверждать, что бессознательный человек (то есть «тень») и состоит не только из нравственно предосудительных тенденций, но и из позитивных качеств - таких, как нормальные инстинкты, уместные реакции, способность к реалистичному восприятию действительности, творческие порывы и т. д.» [3, с. 545].

Тень относительно просто понять, но гораздо труднее постичь.

Главная задача - направить в нужное русло энергию Тени. Для обуздания пагубной стороны своей натуры и для того, чтобы жить в гармонии с другими, хотя в то же время открыто выражать свои импульсы и наслаждаться здоровой и творческой жизнью, необходимо использовать функцию Эго [13, с. 273]. Эго это центр или «цензор сознания», это осознание себя и окружающего мира. По мнению Юнга, осознания своих отрицательных качеств обычно оказывается достаточно для достижения результата. Юнг пишет: «Наши страдающие от внутренних разладов современники только лишь “ситуативные невротики”, их болезненное состояние исчезает, как только исчезает пропасть между Эго и бессознательным» $[15$, с. 161]. Осознание теневых черт и приведение их в соответствие с собственным Эго способствуют усилению и оздоровлению сознания. Другими словами, это «включение бессознательного в сферу осмысленного» [5, c. 16]. Человеку в этом может помочь процесс индивидуации, как движение к целостности с помощью интеграции сознательных и бессознательных частей личности.

Таким образом, мы видим, что для развития человеку необходимо не только осознать свою Тень, но и принять ее, чтобы контролировать, а также работать над собственным развитием, борясь с теми качествами и наклонностями, которые находятся в «Тени». 
Исследование Тени представляет не только теоретический интерес. Динамичность и интенсивность современной жизни заставляют человека все больше внимания уделять своей психике, работе по совершенствованию и развитию своей личности. Ему предлагается в этом плане много услуг типа тренингов личностного роста, которые зачастую играют деструктивную роль. Поэтому повышение уровня психологических знаний очень актуально.

\section{СПИСОК ЛИТЕРАТУРЫ}

1. Андерсен, Х. К. Тень / Х. К. Андерсен // Новое платье короля: сказки и истории / Х. К. АНдерсен. - М. : Худож. лит., 1974. - 208 с.

2. Гейман, Н. Американские боги / Н. Гейман. - М. : АСТ, 2016. - 640 c.

3. Глоссарий // Карл Густав Юнг: дух и жизнь. - М. : Практика, 1996. -560 с.

4. Гофман, Э. Т. А. Приключения в новогоднюю ночь / Э. Т. А. Гофман // Новеллы / сост. Н. А. Жирмунская. - Л. : Лениздат, 1990. -607 с.

5. Иойлева, Г. В. Теоретические аспекты функционирования и развития сознания / Г. В. Иойлева // Вестник Волгоградского государственного университета. Серия 7, Философия. Социология и социальные технологии. - 2014. - № 4 (24). - С. 15-23.

6. Кэмпбелл, Дж. Тысячеликий герой / Дж. Кэмпбелл. - СПб. : Питер, 2016. - 352 с.

7. Ле Гуин, У. Волшебник Земноморья / У. Ле Гуин. -СПб. : Азбука : Азбука-Аттикус, 2015. -544 с.

8. Немецкая коллекция. Адельберт фон Шамиссо. Странная история Петера Шлемиля = Adelbert von Chamisso. Peter Schlemihls wundersame Geschichte. - М. : Изд-во ВКН, 2016. - 288 c.

9. Ницше, Ф. Странник и его тень / Ф. Ницше // Малое собрание сочинений / Ф. Ницше. - СПб. : Азбука-классика, 2010. - 1056 с.

10. Спирова, Э. М. Архетипы в житейской повседневности / Э. М. Спирова // Знание. Понимание. Умение. - 2009. - № 4. - С. 146-151.

11. Стивенсон, Р. Л. Странная история доктора Джекила и мистера Хайда / Р. Л. Стивенсон // Собр. соч. В 5 т. Т. 1. - М. : Правда, 1981. -493 с.

12. Уайльд, О. Рыбак и его душа / О. Уайльд // Малое собрание сочинений / О. Уайльд. - СПб. : Азбука : Азбука-Аттикус, 2014. - 832 с.

13. Фрейд, 3. Опасные желания. Что движет человеком? / 3. Фрейд, К. Юнг. - М. : Алгоритм, 2014. $-288 \mathrm{c}$.

14. Шварц, Е. Л. Тень / Е. Л. Шварц // Пьесы / Е. Л. Шварц. - М. : Сов. писатель, 1982. - 584 с.
15. Юнг, К. Г. Очерки по психологии бессознательного / К. Г. Юнг. - М. : Когито-Центр, 2013. - 352 с.

16. Юнг, К. Г. Структура психики и архетипы / К. Г. Юнг. - М. : Акад. проект, 2015. -328 с.

17. Franz, M.-L. von. Der Schatten und das Böse im Märchen / M.-L. von Franz. - Droemer : Knaur, 1991. - 303 S.

18. Page, S. The shadow and the counsellor: working with darker aspects of the person, role and profession / S. Page. - L. ; N. Y. : Taylor \& Francis e-Library, 1999. - $169 \mathrm{p}$.

19. Young adults' perceptions and memories of a televised woman hero / S. L. Calvert, T. A. Kondla, K. A. Ertel, D. S. Meisel// Sex Roles. -2001. - Vol. 45, № 1/2. - P. 31-52.

\section{REFERENCES}

1. Andersen H.K. Ten [Shadow]. Novoe platye korolya: skazki i istorii [Emperor's New Clothes. Tales and Stories]. Moscow, Khudozhestvennaya literatura Publ., 1974. 208 p.

2. Geyman N. Amerikanskie bogi [American Gods]. Moscow, AST Publ., 2016. 640 p.

3. Glossariy [Glossary]. Karl Gustav Yung: dukh i zhizn [Carl Gustav Jung: Spirit and Life]. Moscow, Praktika Publ., 1996. 560 p.

4. Hoffmann E.T.W. Priklyucheniya v Novogodnyuyu noch [Adventures on New Year Eve]. Zhirmunskaya N.A., ed. Novelly [Novels]. Leningrad, Lenizdat Publ., 1990. 607 p.

5. Ioyleva G.V. Teoreticheskie aspekty funktsionirovaniya i razvitiya soznaniya [Theoretical Aspects of Functioning and Development of Consciousness]. Vestnik Volgogradskogo gosudarstvennogo universiteta. Seriya 7 , Filosofiya. Sotsiologiya i sotsialnye tekhnologii [Science Journal of Volgograd State University. Philosophy, Sociology and Social Technologies], 2014, no. 4 (24), pp. 15-23.

6. Campbell G. Tysyachelikiy geroy [The Hero with Thousand Faces]. Saint Petersburg, Piter Publ., 2016.352 p.

7. Le Guin U. Volshebnik Zemnomorya [The Wizard of Earthsea]. Saint Petersburg, Azbuka-Attikus Publ., 2015. $544 \mathrm{p}$.

8. Nemetskaya kollektsiya. Adelbert fon Shamisso. Strannaya istoriya Petera Shlemilya [German Collection. Adelbert von Chamisso. Peter Schlemihl's Strange Story]. Moscow, Izd-vo VKN, 2016. $288 \mathrm{p}$.

9. Nietzsche F. Strannik i ego ten [Wanderer and His Shadow]. Maloe sobranie sochineniy [Small Collections of Works]. Saint Petersburg, Azbukaklassika Publ., 2010. 1056 p. 


\section{ФИЛОСОФИЯ}

10. Spirova E.M. Arkhetipy v zhiteyskoy povsednevnosti [Archetypes in Everyday Humdrum]. Znanie. Ponimanie. Umenie, 2009, no. 4, pp. 146-151.

11. Stivenson R.L. Strannaya istoriya doktora Dzhekila i mistera Khayda [Strange Case of Dr. Jekyll and Mr. Hyde]. Sobranie sochineniy. V 5 t. T. 1 [Collected Works in 5 vols. Vol. 1]. Moscow, Pravda Publ., 1981. 493 p.

12. Wilde O. Rybak i ego dusha [Fisherman and His Soul]. Maloe sobranie sochineniy [Small Collection of Works]. Saint Petersburg, Azbuka-Attikus Publ., 2014. $832 \mathrm{p}$.

13. Freud Z., Jung K. Opasnye zhelaniya. Chto dvizhet chelovekom? [Dangerous Desires. What Drives a Man?]. Moscow, Algoritm Publ., 2014. 288 p.

14. Shvarts E.L. Ten [Shadow]. Pyesy [Plays]. Moscow, Sovetskiy pisatel Publ., 1982. 584 p.
15. Jung K.G. Ocherki po psikhologii bessoznatelnogo [Essays on Psychology of Uncondiciousness]. Moscow, Kogito-Tsentr Publ., 2013.352 p.

16. Jung K.G. Struktura psikhiki i arkhetipy [The Structure of the Psyche and the Archetypes]. Moscow, Akademicheskiy proekt Publ., 2015.328 p.

17. Franz M.-L. von. Der Schatten und das Böse im Märchen. Droemer, Knaur, 1991.303 p.

18. Page S. The Shadow and the Counsellor: Working with Darker Aspects of the Person, Role and Profession. London; New York, Taylor \& Francis e-Library, $1999.169 \mathrm{p}$.

19. Calvert S.L., Kondla T.A., Ertel K.A., Meisel D.S. Young Adults' Perceptions and Memories of a Televised Woman Hero. Sex Roles, 2001, vol. 45, no. 1/2, pp. 31-52.

\section{Information About the Authors}

Olga V. Korkunova, Doctor of Philosophy, Professor, Department of Philosophy and History, Ural State University of Railway Transport, Kolmogorova St., 66, 620034 Ekaterinburg, Russian Federation, ovkor@e1.ru.

Tatyana I. Bushueva, Postgraduate Student, Department of Philosophy and History, Ural State University of Railway Transport, Kolmogorova St., 66, 620034 Ekaterinburg, Russian Federation, TBushueva@usurt.ru.

\section{Информация об авторах}

Ольга Владимировна Коркунова, доктор философских наук, профессор кафедры философии и истории, Уральский государственный университет путей сообщения, ул. Колмогорова, 66, 620034 г. Екатеринбург, Российская Федерация, ovkor@el.ru.

Татьяна Ивановна Бушуева, аспирант кафедры философии и истории, Уральский государственный университет путей сообщения, ул. Колмогорова, 66, 620034 г. Екатеринбург, Российская Федерация, TBushueva@usurt.ru. 